Sains Malaysiana 47(8)(2018): 1787-1794

http://dx.doi.org/10.17576/jsm-2018-4708-17

\title{
Physicochemical and Structural Characterization of Surface Modified Electrospun PMMA Nanofibre
}

\author{
(Pencirian Fizikokimia dan Struktur bagi Permukaan Termodifikasi Elektroputaran Nanogentian PMMA)
}

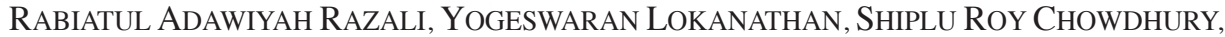
AMINUDDIN SAIM \& RUSZYMAH HAJI IDRUS*

\begin{abstract}
Although electrospun poly(methyl methacrylate) (PMMA) may mimic structural features of extracellular matrix, its highly hydrophobic nature causes reduced cell attachment. This study analysed the physicochemical and structural changes of the surface modified PMMA nanofiber. The electrospun PMMA nanofibers (PM) were surface-treated as follows: PM alone, collagen coated-PM (PM-C), UV-irradiated PM (PM-UV), collagen coated UV-irradiated PM (PM-C-UV) and collagen coated-PM crosslinked with genipin (PM-C-GEN). They were subjected to scanning electron microscopy, Fourier transform infrared (FTIR), cell attachment analysis, X-ray photoelectron spectroscopy (XPS), atomic force microscopy and X-ray powder diffraction (XRD). The surface roughness was lower in PM-C-UV group compared to others. Based on FTIR results, all expected functional group were present in all groups. XPS result showed that there are changes in the mass concentration of UV-treated surfaces and in the collagen coated surfaces. All PM groups showed amorphous nature through XRD. UV irradiation and collagen coating were shown to increase PM's functional groups and modify its surface, which contributed to the increased attachment of cells onto the inert PM scaffold. As conclusion, collagen coated UV irradiated PMMA provided a better surface for cell to attach hence are suitable to be used further as scaffold for in vitro model.
\end{abstract}

Keywords: Electrospun nanofiber; PMMA; scaffold; surface modification; UV irradiation

\section{ABSTRAK}

Walaupun elektroputaran poli(metil metakrilat) (PMMA) boleh memimik sifat struktur matriks ekstrasel, ianya terlalu hidrofobik lantas menyebabkan pengurangan pelekatan sel. Kajian ini telah menganalisis perubahan fizikokimia dan strukur permukaan termodifikasi nanogentian PMMA. Permukaan terawat nanogentian PMMA (PM) yang telah dielektroputar terbahagi seperti berikut: PM sahaja, PM bersalut kolagen (PM-C), PM diradiasi dengan UV bersalut kolagen (PM-UV), dan PM bersalut kolagen disilang dengan genipin (PM-C-GEN). Antara analisis yang dijalankan adalah mikroskopi elektron penskanan (SEM), inframerah transformasi Fourier (FTIR), analisis pelekatan sel, spektroskopi fotoelektron sinar-X (XPS), mikroskopi daya atom (AFM) dan pembelauan sinar-X (XRD). Kekasaran permukaan kumpulan $P M$-C-UV adalah kurang berbanding dengan yang lain. Berdasarkan hasil FTIR, semua kumpulan berfungsi yang dijangka wujud dalam semua kumpulan. Keputusan XPS menunjukkan bahawa terdapat perubahan dalam kepekatan jisim pada permukaan yang telah di UV radiasi dan yang telah disalut kolagen. XRD analisis menunjukkan semua kumpulan PM mempunyai sifat amorf. Sinar UV dan salutan kolagen telah menyebabkan peningkatan di dalam kumpulan berfungsi PM lantas mengubah suai permukaannya dan menyebabkan peningkatan pelekatan sel dalam perancah PM yang lengai. Kesimpulannya, PMMA diradiasi dengan UV bersalut kolagen adalah permukaan yang lebih baik untuk pelekatan sel dan menjadikannya sesuai untuk digunakan sebagai perancah model in vitro.

Kata kunci: Elektroputaran nanogentian; PMMA; perancah; permukaan terubah; sinar UV

\section{INTRODUCTION}

Electrospinning is a technique that can be used to fabricate nanofiber scaffold. It involves a process, where polymer solution either synthetic or natural, are charged with high voltage power resulting in streams of nanofiber ranging from $100 \mathrm{~nm}$ to $5 \mu \mathrm{m}$ (Gupta et al. 2005; Reneker \& Yarin 2008). This type of scaffold can be used for various biomedical application such as scaffolds for tissue model, filter membrane, scaffold for drug delivery and it has been used as carrier in delivering cell to the targeted site (Gopal et al. 2006; Pham et al. 2006; Sheikh et al. 2015; Sill \& von Recum 2008).

Poly (methyl methacrylate) (PMMA) is a biocompatible polymer that can be electrospun into nanofiber. Electrospun PMMA nanofibers have been used as scaffold for several types of cells including respiratory epithelium (Rabiatul et al. 2015), human dermal fibroblast (Liu et al. 2009), human kidney 2 (HK-2) cell line (Polini et al. 2010) and osteoblast cell (Son et al. 2013). It has been shown that electrospun nanofiber helps in attachment of the cells due 
to the topography of the scaffolds that have similarities to the extracellular matrix (ECM) structure.

Physicochemical properties of nanofiber scaffold play a major role in influencing the cell's behavior on scaffold especially in cell attachment and proliferation (Lee \& Livingston Arinzeh 2011). Preferred nanofiber size, porosity, roughness, wettability and bioactive functionalized surfaces can be determined by manipulating the parameter during nanofiber fabrication and by performing surface modification (Sheikh et al. 2015). The majority of scaffold surfaces including electrospun PMMA nanofiber are inert and hydrophobic hence are less likely to be biocompatible (Goddard \& Hotchkiss 2007). Surface with intermediate wettability is proven to be the best for cell adhesion (Pashkuleva et al. 2010).

There are several techniques in performing surface modification such as wet chemical treatment, silane monolayer and ionized gas treatment (Goddard \& Hotchkiss 2007). Each technique has its own advantages and disadvantages. For example, wet chemical treatment will generate chemical waste while ultraviolet (UV) irradiation may not. The selection of surface modification technique depends on the intended application, the production scale, and the type of bioactive compounds and cells that need to be bound on the surface (Goddard \& Hotchkiss 2007; Tang et al. 2008).

UV irradiation has been used to modify the surface of thin films, microcarriers, electrospun nanofibers, synthetic materials and natural materials (Gongjian et al. 1996; Kaczmarek \& Chaberska 2009; Olbrich et al. 2007; Song et al. 2001). Several studies have shown that irradiating the surface with UV cause changes to the surface properties such as increasing presence of functional group e.g. carboxylic acid group (Eve \& Mohr 2009; Situma et al. 2005). The introduction of functional group and the addition of oxygen atom increases the surface energy hence changes the materials wettability properties and makes it more biocompatible (Nie et al. 1999; Pashkuleva et al. 2010).

Crosslinkers are usually used to stabilize the physical structure of a scaffold (Bigi et al. 2002; Lai 2012). Crosslinkers decrease the biodegradability of scaffold, which allows cells to synthesize their own extracellular matrix (ECM) before the scaffold degrade. Two commonly used crosslinkers are glutaraldehyde (GA) and 1-Ethyl-3-(3dimethylaminopropyl) carbodiimide (EDC). However, they possess cytotoxic effect on cells (Lien et al.2008; Yoo et al. 2011). Genipin, a chemical compound derived from fruit extract of Gardenia jasminoides, is found to be less toxic to cells. Several studies have shown the usage of genipin as a natural crosslinker in comparison with other synthetic crosslinkers such as GA and EDC (Feng et al. 2013; Ko et al. 2007; Lai 2012; Lien et al. 2008). However, based on previous study, the non-cytotoxic concentration of genipin varies depending on the type of cell (Wang et al. 2011). In this study, genipin will be used to increase the amount of collagen adsorbed onto nanofiber surface in order to enhance the cell adhesion and proliferation.
Previous study performed in our lab showed that the usage of genipin caused higher collagen adherence to PMMA nanofiber compared to the UV-irradiated surface and direct collagen coating. However, it was found that respiratory epithelial cells (RECs) attached more on UV-irradiated PMMA nanofiber surface compared to the PMMA surface containing higher amount of collagen (Rabiatul et al.2015). Therefore, in this study, the physicochemical properties of PMMA nanofiber surfaces modified by UV treatment and collagen coating (with or without genipin crosslink) were analyzed.

\section{MATERIALS AND METHODS}

This study was approved by Universiti Kebangsaan Malaysia Research Ethics Committee (FF-2014-209).

\section{PMMA NANOFIBER FABRICATION}

$5 \%(\mathrm{w} / \mathrm{v})$ PMMA solution was used to fabricate nanofiber. Briefly, PMMA (Mw=350kDa) powder (Sigma-Aldrich, USA) was dissolved in 1, 1, 1, 3, 3, 3-Hexafluoro-2propanol (HFIP; Sigma-Aldrich, USA) and stirred overnight to dissolve it completely. The viscous solution was loaded into $1 \mathrm{~mL}$ plastic syringe with blunt $19 \mathrm{G}$ needle. Electrospinning was performed with flow rate of 1.00 $\mathrm{mL} / \mathrm{h}$, applied voltage of $10 \mathrm{kV}$ for $10 \mathrm{~min}$ with $10 \mathrm{~cm}$ distance of needle to static collector (Rabiatul et al. 2015).

\section{SURFACE FUNCTIONALIZATION}

Nanofiber sheets were divided into four groups; PMMA nanofiber (PM), collagen coated PMMA nanofiber (PM-C), genipin-crosslinked-collagen coated PMMA nanofiber (PM-C-GEN), and UV-irradiated collagen coated PMMA nanofiber (PM-C-UV). All collagen coated scaffold groups were subjected to overnight collagen coating at $4^{\circ} \mathrm{C}$ with $10 \mu \mathrm{g} / \mathrm{cm}^{2}$ collagen type 1 rat tail (GIBCO). For PM-C-GEN group, $0.002 \%$ (V/V) genipin (Wako Chemicals USA, Inc.) was added into the collagen coating solution. For PM-C-UV, PMMA nanofibers were radiated with UV for $6 \mathrm{~h}(254 \mathrm{~nm}$, Safemate Series, Class II Biological Safety Cabinet, Biocabinets Australia Pty Ltd) prior collagen coating. After coating with collagen, the samples were washed with Dulbecco's Phosphate Buffered Saline (DPBS) and were air dried in bio-safety cabinet for $3 \mathrm{~h}$ before being used.

\section{SURFACE TOPOGRAPHY}

The PMMA nanofiber sheets were subjected to SEM observation. For SEM analysis, the nanofiber sheets were fixed with glutaraldehyde for at least $24 \mathrm{~h}$ at $4^{\circ} \mathrm{C}$ and then washed three times with $0.1 \mathrm{M}$ sodium cacodylate solution. The samples were then post-fixed with $1 \%$ osmium tetraoxide for $2 \mathrm{~h}$ at $4{ }^{\circ} \mathrm{C}$ and dehydrated with increasing concentration of acetone $(35,50,75$, and $95 \%$ for $10 \mathrm{~min}$ each and three changes in $100 \%$ for $15 \mathrm{~min}$ ). The dehydrated samples were transferred into specimen basket and immersed in $100 \%$ acetone and dried with critical 
point dryer (Baltec $030 \mathrm{CPD}$, Liechtenstein, Switzerland) for approximately $30 \mathrm{~min}$. Thereafter, the samples were mounted on copper stub using double-sided carbon tape and sputter-coated (Polaron E5100 sputter coater, Milan, Italy) with gold-palladium. The samples were then examined using Phenom G2 Pro Desktop scanning electron microscope (Phenom-World, Netherlands).

\section{FUNCTIONAL GROUP DETECTION}

Presence of functional group on the surface treated PMMA nanofibers was analyzed using FTIR and XPS method. The infrared spectra of the samples were recorded on a Spectrum 400 FT-IR/FTNIR and Spotlight 400 Imaging System (Perkin Elmer, UK) using the attenuated total reflection (ATR) method for sample preparation technique. The X-ray Photoelectron spectroscopy (XPS) analysis of the samples was performed using XPS Axis Ultra DLD (Kratos, Manchester, UK) equipped with monochromatic $\mathrm{Al} \mathrm{K} \alpha$ radiation $(\mathrm{BE}=1486.6 \mathrm{eV})$. The samples were analyzed inside analysis chamber with pressure about $1 \mathrm{x}$ $10^{-10} \mathrm{~Pa}$. The binding energy of $\mathrm{C} 1 \mathrm{~s}, 284.5 \mathrm{eV}$ was used as a reference.

\section{TOTAL CELL ATTACHMENT}

Respiratory Epithelial Cells (RECs) were procured following previous method (Rabiatul et al. 2015). 80\% confluency REC were trypsinized and seeded onto the scaffold. At day 4 the cells on the scaffolds were fixed, stained with 4', 6-diamidino-2-phenylindole (DAPI) and the scaffolds were observed under fluorescence microscope as described previously (Rabiatul et al. 2015). The cells were counted and compared between groups.

\section{SURFACE ROUGHNESS}

Surface roughness was analyzed using Bio-AFM. The sample was fixed with 4\% Paraformaldehyde and was viewed using BioScope Resolve ${ }^{\mathrm{TM}}$ BioAFM (Bruker AXS Corporation, Santa Barbara, CA, USA). Surface roughness was calculated by measuring the $\mathrm{R}_{\mathrm{QMS}}$ obtained from 5 different spots using Gwyddion software (Czech Meteorology Institute, Czech Republic).

\section{CRYSTALLINITY PROPERTIES}

The phase and structure of the surface treated PMMA nanofibers were analyzed using the X-ray diffraction (XRD) method (Bruker D8 Advance diffractometer) with $\mathrm{CuK} \alpha$ radiation $(40 \mathrm{kV}, 40 \mathrm{~mA}, \lambda=0.15406 \mathrm{~nm})$ to record angle $2 \theta$ from $10^{\circ}$ to $80^{\circ}$.

\section{STATISTICAL ANALYSIS}

The data were compared with ANOVA analysis using GraphPad Prism Version 7. A p-value $\leq 0.05$ was considered significantly different. Data are shown as mean \pm SD.

\section{RESULTS AND DISCUSSION}

Biomaterials fabrication and its surface modification plays major role in developing in vitro model. This study was performed to answer the question of our previous finding on why UV-irradiated collagen coated PMMA nanofiber (PMC-UV) has higher respiratory epithelial cell attachment on the surface even though it has lower amount of collagen attachment compared to the genipin-crosslinked-collagen coated PMMA nanofiber (PM-C-GEN) (Rabiatul et al. 2015). In order to investigate this phenomenon, SEM, FTIR, cell attachment analysis, XPS, AFM, and XRD were performed.

\section{SURFACE TOPOGRAPHY (SEM)}

SEM image of PMMA nanofiber sheet showed that it has randomly aligned fibers without droplets and beads and has a smooth whitish appearance (Figure 1). All collagen coated PMMA groups showed presence of collagen on the nanofibers and it was observed that PM-C-GEN has more collagen attached to its surface with deposition of collagen bulk in between the fibers (Figure 1). This is probably due to the crosslinking of collagen with genipin and adhesion of this complex to PM nanofiber. Genipin crosslinking reacts in a similar manner as glutaraldehyde, which after binding with collagen it can bind to another genipin group (Englert et al. 2007). Type I collagen exists as long, thin fibrils comprising of various types of amino acid that are able to bind to genipin molecules forming genipin-collagen complexes capable of binding to each other (Yoo et al. 2011). This collagen-genipin-genipin-collagen complex will bind to the nanofiber leading to higher amount of collagen attachment (Rabiatul et al. 2015).

\section{FUNCTIONAL GROUP DETECTION (FTIR)}

FTIR analysis showed that PMMA nanofiber has $\mathrm{C}-\mathrm{H}$ bond stretching vibrations of $-\mathrm{CH}_{3}$ and $-\mathrm{CH}_{2}$ groups at 3050$2990 \mathrm{~cm}^{-1}$ (Figure 2). The band at $1730 \mathrm{~cm}^{-1}$ shows presence of carboxyl group. The band at $1395-1450 \mathrm{~cm}^{-1}$ can be assigned to $\mathrm{C}-\mathrm{H}$ bonds of the $-\mathrm{CH}_{3}$. It was also observed that PMMA has absorption band from 1040-1260 $\mathrm{cm}^{-1}$, which can be attributed to $\mathrm{C}-\mathrm{O}-\mathrm{C}$ stretching vibration. The two bands at 1388 and $754 \mathrm{~cm}^{-1}$ can be attributed to the a-methyl group vibrations. The bonds formation at 880-960 $\mathrm{cm}^{-1}$ refers to $\mathrm{C}-\mathrm{O}-\mathrm{C}$ deformation vibration. There were no differences in peaks present between UV irradiated PMMA (PM-UV) and non-irradiated PM. However, with presences of collagen (PM-C, PM-C-UV, and PM-C-GEN), there was a noticeable peak at 1560 and $1650 \mathrm{~cm}^{-1}$, which represent asymmetric stretching of the nitro functional group $\left(-\mathrm{NO}_{2}\right)$ and N-H bending, respectively. Presences of the nitro functional group and N-H binding shows that the PM has been successfully coated with collagen. Absorption bands at $3437 \mathrm{~cm}^{-1}$ can be attributed to the $-\mathrm{OH}$ group stretching vibrations due presence of moisture (Figure 2). All PMMA nanofiber group (PM, PM-C, PM-C-UV, PM-C-GEN) have the same PMMA bond that has been reported in previous studies (Duan et al. 2016, 2008). 

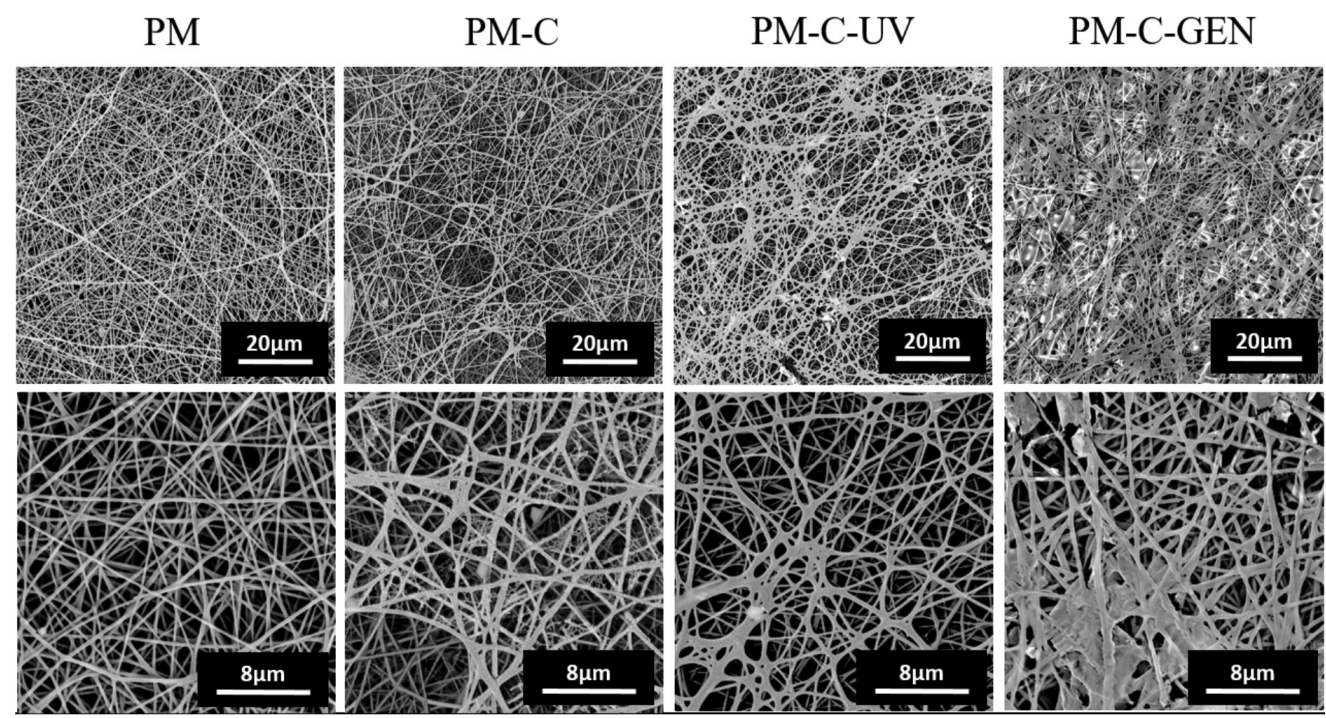

FIGURE 1. SEM images of surface modified PMMA nanofibers. The collagen bulk deposition in-between the PMMA fibers was observed to be higher in PM-C-GEN group compared to the other collagen coated groups

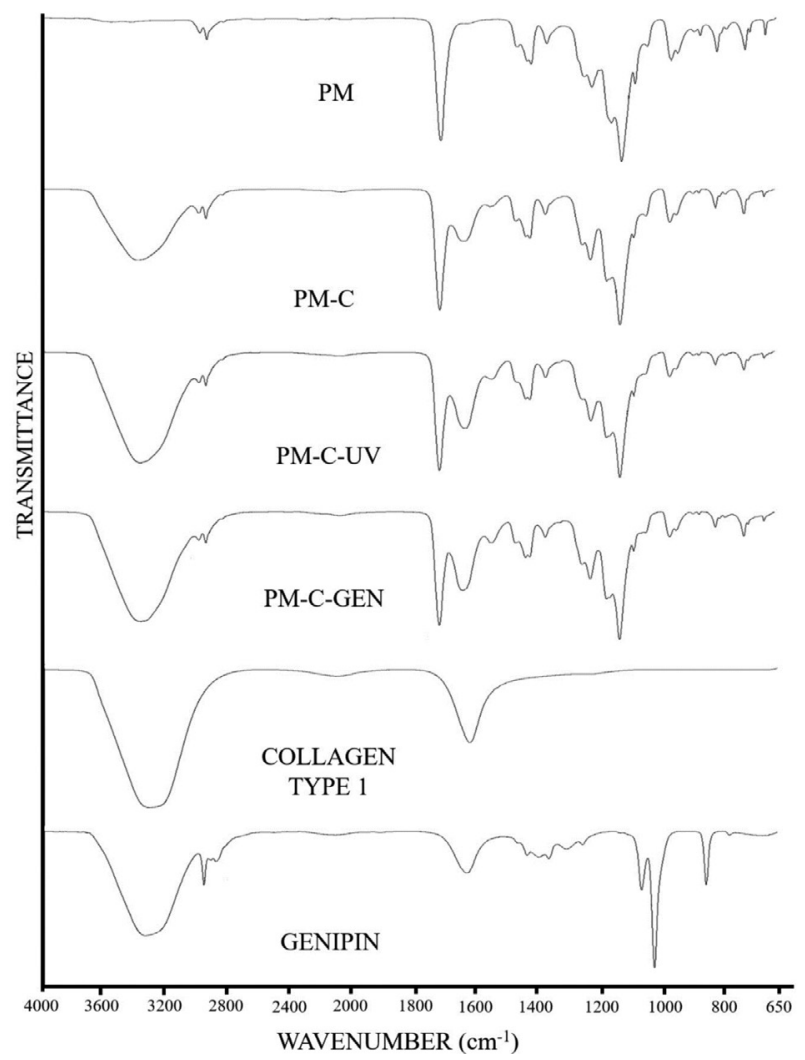

FIGURE 2. FTIR spectra for surface modified PMMA nanofibers. Presences of peak at 1560 and $1650 \mathrm{~cm}^{-1}$ represent asymmetric stretching of the nitro functional group $\left(-\mathrm{NO}^{2}\right)$ and $\mathrm{N}-\mathrm{H}$ bending in PM-C, PM-C-UV, and PM-C-GEN

\section{TOTAL CELL ATTACHMENT}

Previous study has shown that cells are prone to attach to PM-C-UV group (Rabiatul et al. 2015), therefore, cell attachment analysis were further performed to confirm this. Significantly higher number of RECs were found to attach onto PM-C-UV scaffold compared to others (Figure 3), confirming our previous findings. There was no significant difference in RECs attachment between PM and PM-C-GEN in term of cell attachment. Higher RECs attachment in PM-C-UV group (Figure 3) can be attributed to increase in functional group due to UV irradiation as shown through XPS results, hence causing more RECs to attach to the surface. UV irradiation also has shown to reduce surface roughness (Figure 5) causing the surface to become more hydrophilic. RECs are prone to attach to intermediate hydrophilic surface compared to hydrophobic surfaces. However, lesser RECs were observed in PM-C-GEN, which might be due to the concentration of genipin used. The genipin concentration-dependent effect differ according to the type of cell. For example, osteoblast is much more sensitive to genipin $(0.01 \%)$ compared to chondrocytes $(0.1 \%)$ (Wang et al. 2011; Yoo et al. 2011). Due to the binding patterns of genipin to collagen molecules, bulk depositions of collagen genipin complex is likely to occur. This increases the possibilities of collagen to be washed away together with attached cells during culture medium exchange (Polini et al. 2010; Rabiatul et al. 2015).

\section{FUNCTIONAL GROUP QUANTIFICATION (XPS ANALYSIS)}

Due to higher amount of cells found attached in PM-C-UV group, XPS was used to analyze the surface composition and binding energy (BE) of UV-irradiated PMMA surfaces with or without collagen (Figure 4). The percentage of mass concentration and binding energy of $\mathrm{C} 1 \mathrm{~s}$ and $\mathrm{O} 1 \mathrm{~s}$ obtained were summarized in Table 1. UV irradiation to the PM nanofiber surface caused decreased in $\mathrm{C}-\mathrm{C} / \mathrm{CH}_{3}$ and $\mathrm{C}-\mathrm{O}-\mathrm{C}$ concentration and increased in $\mathrm{C}=\mathrm{O}, \mathrm{O}=\mathrm{CH}_{3}$ and $\mathrm{O}-\mathrm{C}=\mathrm{O}$ functional group concentration compared to the non-treated surface. This might be due to chain scission 
A
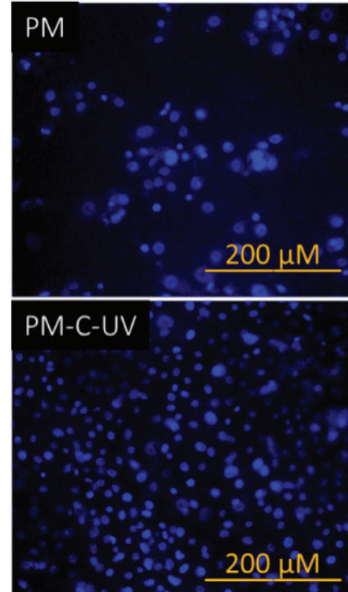
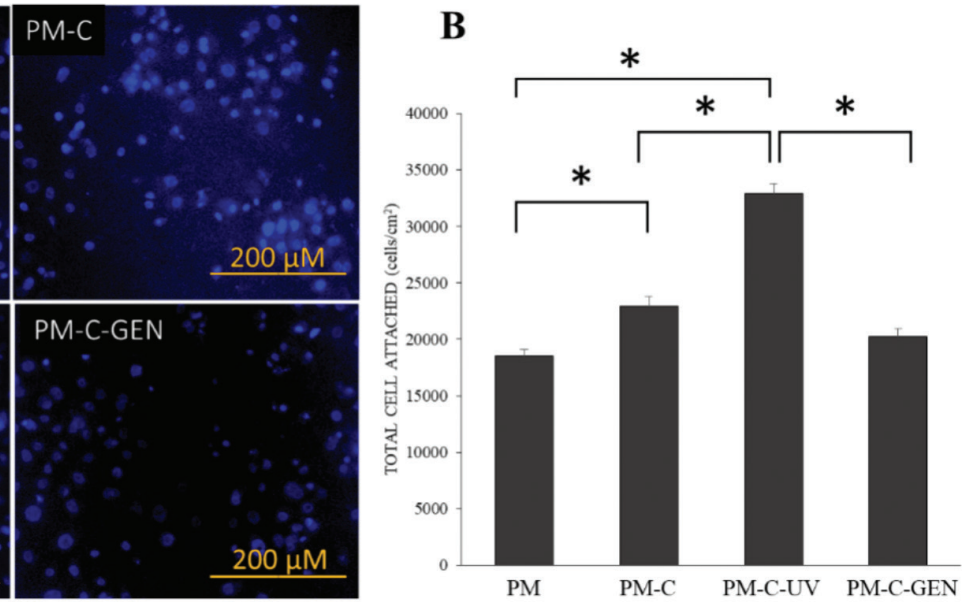

FIGURE 3. Nuclear staining of REC's nucleus and graph of total amount of cells attached on nanofiber sheets vs group. PM-C-UV has the highest amount of cell attached compared to the other group. *indicate significant difference. $(p<0.05)$

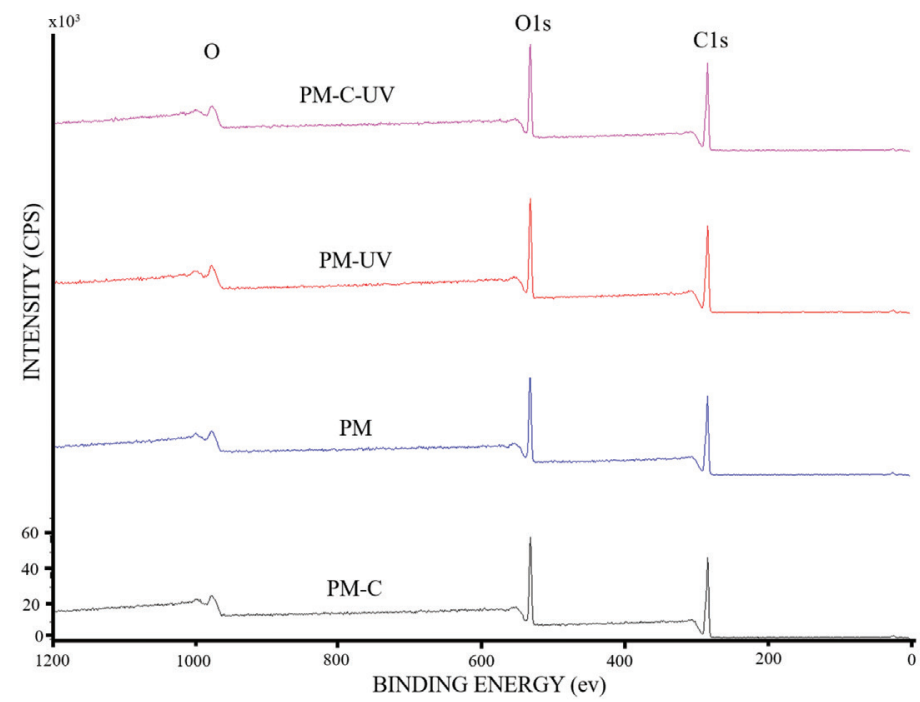

FIGURE 4. XPS wide scan spectra of PM nanofibers

TABLE 1. Summary of binding energy $(\mathrm{eV})$, mass concentration and peak assignment

\begin{tabular}{ccccccc}
\hline & & \multicolumn{5}{c}{ MASS CONCENTRATION, \% } \\
\cline { 3 - 5 } GROUP & $\begin{array}{c}\text { BINDING } \\
\text { ENERGY }(\mathrm{eV})\end{array}$ & PM & PM-UV & PM-C & PM-C-UV & PEAK ASSIGNMENT \\
\hline O 1 & 531.87 & 11.65 & 19.4 & 7.93 & 16.92 & $\mathrm{C}=\mathrm{O}$ \\
O 2 & 533.48 & 16.3 & 8.55 & 9.375 & 12.32 & $\mathrm{C}-\mathrm{O}-\mathrm{C}$ \\
c 1 & 285 & 44.75 & 39.3 & 48.54 & 40.61 & $\mathrm{C}-\mathrm{C} / \mathrm{CH} 3$ \\
c 2 & 286.6 & 14.66 & 19.22 & 17.175 & 15.24 & O-C=O \\
c 3 & 288.71 & 12.65 & 13.52 & 16.76 & 14.9 & O-CH3 \\
\hline
\end{tabular}

of polymer happening on PM surface (Kasahara et al. 2012; Koo \& Jang 2009). Photo-oxidation caused by UV irradiation also alters the PM surface by introducing oxygen functional groups to the PM nanofiber (Kasahara et al.2012; Koo \& Jang 2009). The photo-scission and photo-oxidation of PM surface may be the major contributing factor to the increase in hydrophilic property of the PM-UV. As the surface becomes more oxidized, the surface becomes more hydrophilic (Goddard \& Hotchkiss 2007; Pashkuleva et al. 2010). Coating the surface with collagen (PM-C and PM-C$\mathrm{UV}$ ) caused the $\mathrm{O}-\mathrm{C}=\mathrm{O}$ and $\mathrm{O}-\mathrm{CH}_{3}$ mass concentration to be higher than control group (PM). Other than that, lower 

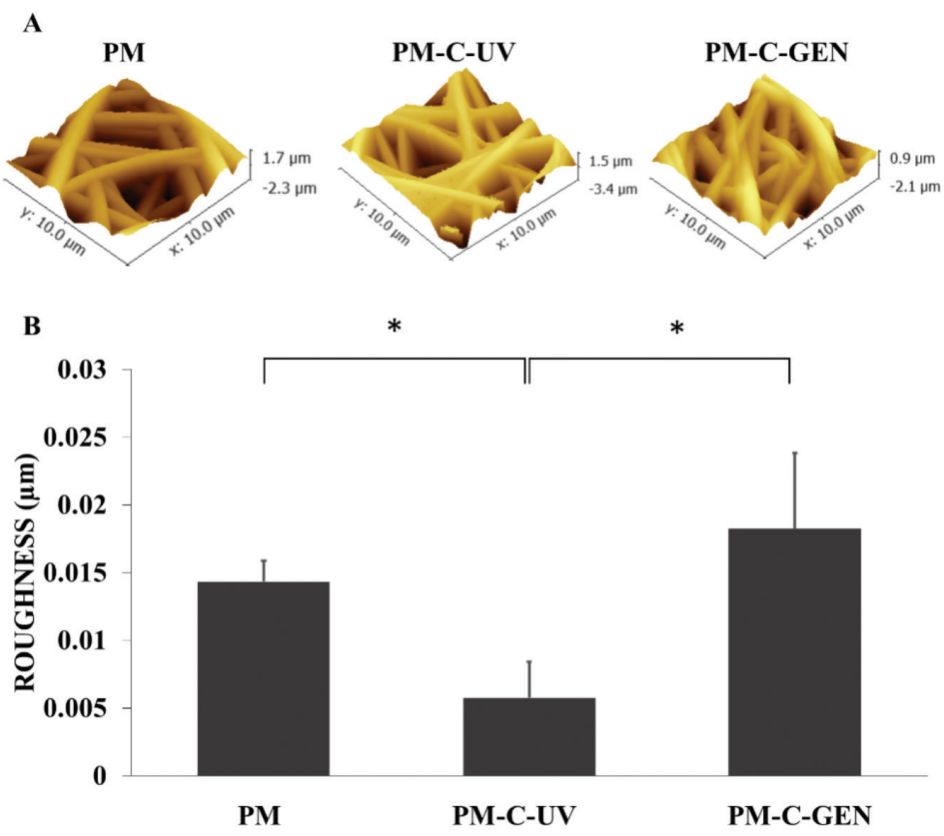

FIGURE 5. A) AFM images of surface modified PM nanofibers. B) Surface roughness of the nanofibers. PM-C-UV has significantly lower roughness compared to the other tested groups. *indicate significant difference. $(p<0.05)$

concentration of $\mathrm{C}-\mathrm{O}-\mathrm{C}, \mathrm{C}=\mathrm{O}$ and $\mathrm{CH}_{3}$ in PM-C compared to control group (PM) were also observed.

\section{SURFACE ROUGHNESS (AFM)}

Figure 5 shows the surface roughness analysis using AFM. The root mean square (RMS) roughness $\left(R_{q}\right)$ showed that PM-C-UV has significantly lesser surface roughness $(0.00575 \mu \mathrm{m} \pm 0.002)$ compared to PM and PM-C-GEN and this findings are in confirmation with previous studies (Oláh et al. 2005; Pashkuleva et al. 2010). A rougher surface will lead to high hydrophobic surface which will cause cell attachment to be lower (Pashkuleva et al. 2010; Rabiatul et al. 2015). UV irradiation is known to cause physical changes to the surface of the scaffold by breaking polymeric chains (Braghirolli et al. 2014; Pashkuleva et al. 2010).

\section{CRYSTALLINITY PROPERTIES (XRD)}

All tested group for surface modified PM nanofiber showed amorphous characteristic (Figure 6). Broader diffraction peak present in all group at $15^{\circ}$ corresponds to amorphous PM. XRD analysis of PM nanofiber indicated it has amorphous structure since the crystallinity percentage was less than $25 \%$. Besides that, electrospun nanofiber scaffolds have been shown to have lower crystallinity properties due to rapid loss of solvent and solidification during electrospinning process (Viswanath et al. 2016). Previous studies have shown that more cells attached on surface with higher crystallinity, however, cell attachment also depends on other scaffold properties such as rigidity (Cui \& Sinko 2012).

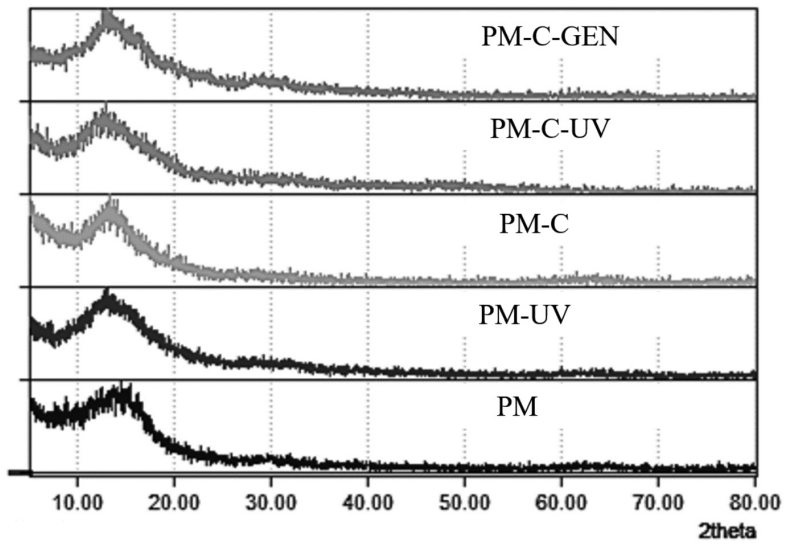

FIGURE 6. XRD pattern of all tested group. Broad diffraction peak shows the amorphous nature of PM nanofiber

\section{CONCLUSION}

It was found that UV irradiation introduced more functional groups to the surface of PMMA nanofiber, which caused reduction in surface roughness and increased hydrophilicity, leading to increase in cell attachment. Meanwhile, genipin crosslinking increased collagen adsorption due to its ability to crosslink collagen in large amount, however cell attachment was found to be reduced. As conclusion, UV irradiation are found to be the best technique for surface modification to enhance the properties of PM scaffold surface making it suitable for development of in vitro model. 


\section{ACKNOWLEDGEMENTS}

The authors would like to thank Universiti Kebangsaan Malaysia for funding this project under grant number FF2014-209, DIP-2012-08 and AP 2013-015 and Centre for Research and Instrumentation Management (CRIM-UKM) for providing FTIR, XRD, and XPS analysis services. The authors have no conflict of interest to report.

\section{REFERENCES}

Bigi, A., Cojazzi, G., Panzavolta, S., Roveri, N. \& Rubini, K. 2002. Stabilization of gelatin films by crosslinking with genipin. Biomaterials 23(24): 4827-4832.

Braghirolli, D.I., Steffens, D., Quintiliano, K., Acasigua, G.A.X., Gamba, D., Fleck, R.A., Petzhold, C.L. \& Pranke, P. 2014. The effect of sterilization methods on electronspun poly (lactide-co-glycolide) and subsequent adhesion efficiency of mesenchymal stem cells. Journal of Biomedical Materials Research Part B: Applied Biomaterials 102(4): 700-708.

Gongjian, B., Yunxuan, W. \& Xingzhou, H. 1996. Surface modification of polyolefine by UV lightozone treatment. Journal of Applied Polymer Science 60: 2397-2402.

Cui, H. \& Sinko, P.J. 2012. The role of crystallinity on differential attachment/proliferation of osteoblasts and fibroblasts on poly (caprolactone-co-glycolide) polymeric surfaces. Frontiers of Materials Science 6(1): 47-59.

Duan, G., Zhang, C., Li, A., Yang, X., Lu, L. \& Wang, X. 2008. Preparation and characterization of mesoporous zirconia made by using a poly (methyl methacrylate) template. Nanoscale Research Letters 3(3): 118.

Englert, C., Blunk, T., Müller, R., von Glasser, S.S., Baumer, J., Fierlbeck, J., Heid, I.M., Nerlich, M. \& Hammer, J. 2007. Bonding of articular cartilage using a combination of biochemical degradation and surface cross-linking. Arthritis Research \& Therapy 9(3): R47.

Eve, S. \& Mohr, J. 2009. Study of the surface modification of the PMMA by UV-radiation. Procedia Engineering 1(1): 237-240.

Feng, H., Zhang, L. \& Zhu, C. 2013. Genipin crosslinked ethyl cellulose-chitosan complex microspheres for antituberculosis delivery. Colloids Surf B Biointerfaces 103: 530-537.

Goddard, J.M. \& Hotchkiss, J.H. 2007. Polymer surface modification for the attachment of bioactive compounds. Progress in Polymer Science 32(7): 698-725.

Gopal, R., Kaur, S., Ma, Z., Chan, C., Ramakrishna, S. \& Matsuura, T. 2006. Electrospun nanofibrous filtration membrane. Journal of Membrane Science 281(1-2): 581-586.

Gupta, P., Elkins, C., Long, T.E. \& Wilkes, G.L. 2005. Electrospinning of linear homopolymers of poly(methyl methacrylate): Exploring relationships between fiber formation, viscosity, molecular weight and concentration in a good solvent. Polymer 46(13): 4799-4810.

Kaczmarek, H. \& Chaberska, H. 2009. AFM and XPS study of UV-irradiated poly (methyl methacrylate) films on glass and aluminum support. Applied Surface Science 255(13): 6729-6735.

Kasahara, T., Shoji, S. \& Mizuno, J. 2012. Surface modification of polyethylene terephthalate (PET) by 172-nm excimer lamp. Transactions of The Japan Institute of Electronics Packaging 5(1): 47-54.
Ko, C.S., Wu, C.H., Huang, H.H. \& Chu, I.M. 2007. Genipin cross-linking of type ii collagen-chondroitin sulfatehyaluronan scaffold for articular cartilage therapy. Journal of Medical and Biological Engineering 27(1): 7-14.

Koo, G.H. \& Jang, J.H. 2009. Hydrophilic modification of poly (ethylene oxide) by UV irradiation. Textile Coloration and Finishing 21(5): 16-20.

Lai, J.Y. 2012. Biocompatibility of genipin and glutaraldehyde cross-linked chitosan materials in the anterior chamber of the eye. Int. J. Mol.Sci. 13(9): 10970-10985.

Lee, Y.S. \& Livingston Arinzeh, T. 2011. Electrospun nanofibrous materials for neural tissue engineering. Polymers 3(4): 413426.

Lien, S.M., Li, W.T. \& Huang, T.J. 2008. Genipin-crosslinked gelatin scaffolds for articular cartilage tissue engineering with a novel crosslinking method. Materials Science and Engineering: C 28(1): 36-43.

Liu, Y., Ji, Y., Ghosh, K., Clark, R.A., Huang, L. \& Rafailovich, M.H. 2009. Effects of fiber orientation and diameter on the behavior of human dermal fibroblasts on electrospun PMMA scaffolds. J. Biomed. Mater. Res. A 90(4): 1092-1106.

Nie, H.Y., Walzak, M.J., Berno, B. \& McIntyre, N.S. 1999. Atomic force microscopy study of polypropylene surfaces treated by uv and ozone exposure modification of morphology and adhesion force. Applied Surface Science 144: 627-632.

Oláh, A., Hillborg, H. \& Vancso, G.J. 2005. Hydrophobic recovery of UV/ozone treated poly (dimethylsiloxane): Adhesion studies by contact mechanics and mechanism of surface modification. Applied Surface Science 239(3): 410-423.

Olbrich, M., Punshon, G., Frischauf, I., Salacinski, H.J., Rebollar, E., Romanin, C., Seifalian, A.M. \& Heitz, J. 2007. UV surface modification of a new nanocomposite polymer to improve cytocompatibility. Journal of Biomaterials Science, Polymer Edition 18(4): 453-468.

Pashkuleva,I., Marques, A.P., Vaz, F. \& Reis, R.L. 2010. Surface modification of starch based biomaterials by oxygen plasma or UV-irradiation. Journal of Materials Science: Materials in Medicine 21(1): 21-32.

Pham, Q.P., Sharma, U. \& Mikos, A.G. 2006. Electrospinning of polymeric nanofibers for tissue engineering applications: A review. Tissue Engineering 12(5): 1197-1211.

Polini, A., Pagliara, S., Stabile, R., Netti, G.S., Roca, L., Prattichizzo, C., Gesualdo, L., Cingolani, R. \& Pisignano, D. 2010. Collagen-functionalised electrospun polymer fibers for bioengineering applications. Soft Matter 6(8): 1668.

Rabiatul, A.R., Lokanathan, Y., Rohaina, C.M., Chowdhury, S.R., Aminuddin, B.S. \& Ruszymah, B.H.I. 2015. Surface modification of electrospun poly (methyl methacrylate) (PMMA) nanofibers for the development of in vitro respiratory epithelium model. Journal of Biomaterials Science, Polymer Edition 26(17): 1297-1311.

Reneker, D.H. \& Yarin, A.L. 2008. Electrospinning jets and polymer nanofibers. Polymer 49(10): 2387-2425.

Sheikh, F.A., Ju, H.W., Lee, J.M., Moon, B.M., Park, H.J., Lee, O.J., Kim, J.H., Kim, D.K. \& Park, C.H. 2015. 3D electrospun silk fibroin nanofibers for fabrication of artificial skin. Nanomedicine: Nanotechnology, Biology and Medicine 11(3): 681-691.

Sill, T.J. \& von Recum, H.A. 2008. Electrospinning: Applications in drug delivery and tissue engineering. Biomaterials 29(13): 1989-2006. 
Situma, C., Wang, Y., Hupert, M., Barany, F., McCarley, R.L. \& Soper, S.A. 2005. Fabrication of DNA microarrays onto poly (methyl methacrylate) with ultraviolet patterning and microfluidics for the detection of low-abundant point mutations. Analytical Biochemistry 340(1): 123-135.

Son, S.R., Linh, N.T.B., Yang, H.M. \& Lee, B.T. 2013. In vitro and in vivo evaluation of electrospun PCL/PMMA fibrous scaffolds for bone regeneration. Science and Technology of Advanced Materials 14(1): 015009.

Song, W., So, S.K., Wang, D., Qiu, Y. \& Cao, L. 2001. Angle dependent X-ray photoemission study on UV-ozone treatments of indium tin oxide. Applied Surface Science 177(3): 158-164.

Tang, L., Thevenot, P. \& Hu, W. 2008. Surface chemistry influences implant biocompatibility. Current Topics in Medicinal Chemistry 8(4): 270-280.

Viswanath, V., Maity, S., Bochinski, J.R., Clarke, L.I. \& Gorga, R.E. 2016. Enhanced crystallinity of polymer nanofibers without loss of nanofibrous morphology via heterogeneous photothermal annealing. Macromolecules 49(24): 9484-9492.

Wang, C., Lau, T.T., Loh, W.L., Su, K. \& Wang, D.A. 2011. Cytocompatibility study of a natural biomaterial crosslinkerGenipin with therapeutic model cells. J.Biomed. Mater. Res. B Appl. Biomater. 97(1): 58-65.

Yoo, J.S., Kim, Y.J., Kim, S.H. \& Choi, S.H. 2011. Study on genipin: A new alternative natural crosslinking agent for fixing heterograft tissue. Korean J. Thorac. Cardiovasc. Surg. 44(3): 197-207.
Rabiatul Adawiyah Razali, Yogeswaran Lokanathan, Shiplu Roy Chowdhury \& Ruszymah Haji Idrus*

Tissue Engineering Centre

Universiti Kebangsaan Malaysia (UKM) Medical Centre Jalan Yaa'cob Latiff

56000 Cheras, Kuala Lumpur, Federal Territory Malaysia

Aminuddin Saim

Ear, Nose and Throat Consultant Clinic

KPJ Ampang Puteri Specialist Hospital

Jalan Mamanda 9, Taman Dato Ahmad Razali

68000 Ampang, Selangor Darul Ehsan

Malaysia

Ruszymah Haji Idrus*

Department of Physiology

Universiti Kebangsaan Malaysia

Jalan Yaa'cob Latiff

56000 Cheras, Kuala Lumpur, Federal Territory

Malaysia

*Corresponding author; email: ruszyidrus@gmail.com

Received: 8 January 2018

Accepted: 19 April 2018 